\title{
The Distribution of Heavy Metals and Nutrients along Selangor River and its Adjacent Mining Ponds, Malaysia
}

\author{
R. Daniel, and Nobuyuki Kawasaki
}

\begin{abstract}
Selangor River, one of major rivers in Malaysia, supplies about $70 \%$ of drinking water in Kuala Lumpur areas. There are also many ex-mining ponds along Selangor River, which have been used as an additional water source. Despite its importance, the water quality, especially the distribution and abundance of heavy metals, has been understudied in Selangor River and adjacent mining ponds. Water samples were collected from these areas, and the high concentrations of Aluminum ( $\mathrm{Al})$ and Iron (Fe) were detected, indicating that mining ponds could be the major sources of $\mathrm{Al}$ and $\mathrm{Fe}$. The other heavy metal concentrations were much lower than the limit of allowance levels. In addition, high ammonia concentrations were also observed in some mining ponds, suggesting that they could also be the excess nutrient sources. Additional study is needed to estimate the effects of the heavy metals on the surrounding environments as well as human health risks.
\end{abstract}

Keywords - heavy metal pollution, Nutrient concentrations, Selangor River, ex-tin mining

\section{INTRODUCTION}

A heavy metal is defined as any dense metal or metalloid that is noted for its potential toxicity especially in the environmental contexts [1]. Heavy metals are naturally occurring elements which can be found throughout the earth's crust. The World Health Organization has listed out 10 chemicals or groups of major public concern which also includes some heavy metals such as cadmium (Cd), lead ( $\mathrm{Pb})$, mercury ( $\mathrm{Hg}$ ) and arsenic (As) [2]. Other examples of heavy metals are manganese, chromium, cobalt, nickel, copper (Cu), zinc (Zn), selenium (Se) and silver (Ag). In recent years, environmental contamination by these metals has increased dramatically thus raised ecological and global public health concern [3]. The increase was very significant with growing human exposure in several industrial, agricultural, domestic and technological applications [3]. Common sources of heavy metals in the environment include geogenic, industrial, agricultural, pharmaceutical, and atmospheric sources and domestic effluents [4]. Environmental contamination may also occur due to the metal corrosion, atmospheric deposition, soil erosion of metal ions and leaching of heavy metals, sediment re-suspension and metal evaporation from water resources to soil and ground water [5].

Daniel Ramachandran, Faculty of Science and Biotechnology, University of Selangor, Malaysia

Dr. Nobuyuki Kawasaki, Faculty of Science and Biotechnology, University of Selangor, Malaysia
Many rivers in Malaysia have been a dumping site for wastes including heavy metals for quite some time [6]. Besides direct dumping, the contributions of heavy metals and nutrients to river environments include surface runoff and atmospheric deposition. The automobiles also contribute to the production of heavy metals. In last 10 years, the number of registered vehicles in Malaysia has nearly doubled [7]. Thus, the heavy metal abundance should be continuously increasing in various environments. Despite its importance, there have been a few studies to examine the heavy metal concentrations in Malaysian rivers.

The mining ponds have been distributed in the middle of Selangor River because Malaysia was used to be famous for tin mining. It is estimated there are about 442 different ponds near Selangor River which are formed on the ex-mining areas. The generation of mine water pollution, both during and after mining operations, has characterized the industry worldwide since ancient times [8]. The ex-mining areas could be responsible for the high releases of heavy metals such as $\mathrm{Al}, \mathrm{Fe}$, nickel and silver into the environment. It also releases air pollutants including sulphur dioxide and nitrogen oxides in addition to leaving behind tons of waste tailings, slag, and acid drainage. In 2014, when Kuala Lumpur areas experienced the water deficiency, the mining pond water had been used as an additional water source. Although the water quality of mining ponds was examined and confirmed to be safe, the potential risks of heavy metals released from the mining ponds have not been well-examined yet.

In this study, the water samples along Selangor River as well as the selected mining ponds adjacent to Selangor River were collected in order to estimate the nutrient and heavy metal distributions to Selangor River and elaborate the potential sources of these pollutants. Our data should provide the useful data to manage river waters and mining pond waters more effectively.

\section{MATERIALS AND METHODS}

\section{A. Sampling Location and sampling procedure}

Water samples were collected on February 2015 from 10 sampling points; 8 points in Selangor River and 2 points in one of arm rivers of Selangor River (Fig. 1). The water samples were collected from 3 mining points adjacent to Selangor River which is located in the middle of Selangor River. The samples 
were collected using a bucket and pre-filtered by a $140 \mu \mathrm{m}$ mesh to remove large particles. The collected water was then poured into a 2-L high density polyethylene bottle (Nalgene) and kept in a cooler. Water quality parameters which include $\mathrm{pH}$, temperature, dissolve oxygen (DO), salinity and conductivity were measured using a YSI multimeter.

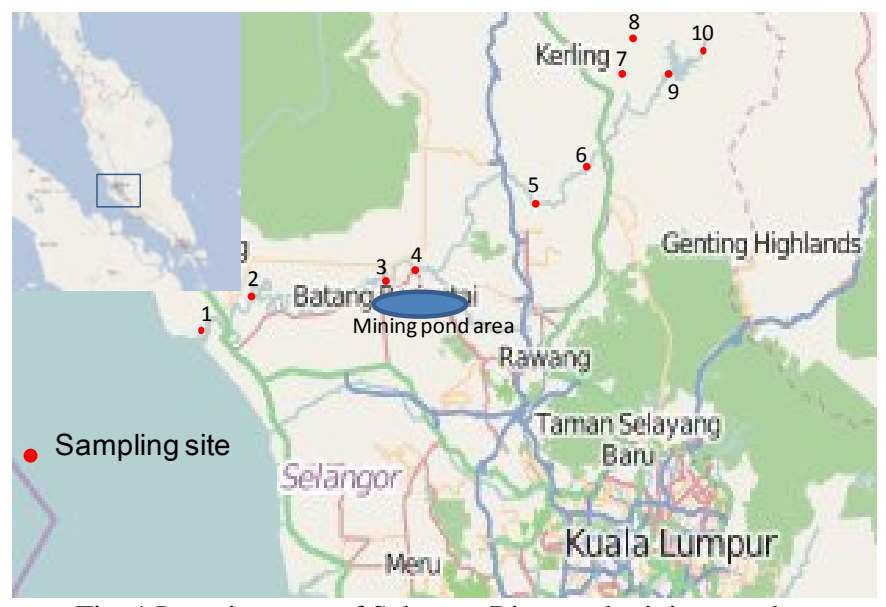

Fig. 1 Location map of Selangor River and mining ponds near Selangor River

\section{B. Sample Preparation and Analysis}

Samples were then taken to laboratory, and filtration was made using glass-fibre filter paper (GF/F, Whatman) with a gentle vacuum. The filtrate was transferred into $60 \mathrm{ml}$ Nalgene bottles for nutrient analyses. Another $200 \mathrm{ml}$ of non-filtered samples were transferred into $250 \mathrm{ml}$ Nalgene bottles for heavy metal analyses. Both bottled samples were stored frozen in $-20^{\circ} \mathrm{C}$ for further analysis.

The non-filtered samples were freeze-dried using Labconco Freeze Dryer at $-50^{\circ} \mathrm{C}$ and 0.12 mbar to remove water content. The dried powder samples weighing between 0.01 and $0.05 \mathrm{~g}$ were placed in a Teflon vessel for heavy metal analyses [9]. 1.5 $\mathrm{ml}$ of mixed acid of $65 \% \mathrm{HNO}_{3}, 30 \% \mathrm{HCl}, 40 \% \mathrm{HF}$ at the ratio of 3:3:2 was added in the Teflon vessel. The Teflon vessel was then inserted into the steel jacket and capped tightly. The Teflon bomb was then placed in the oven (Memmert UN30) at $150^{\circ} \mathrm{C}$ for 7 hours for total digestion. After total digestion, the Teflon bomb was left cool at room temperature. The digested sample was then transferred into a $10 \mathrm{ml}$ polypropylene centrifuge tube. The volume is meshed to make up $10 \mathrm{ml}$ using pure water. The sample was then subjected for analysis using Inductively Coupled Plasma Mass Spectrometry (ICP-MS) at University Malaysia Terengganu (UMT).

Nutrients for filtered samples were analyzed using MD-600 (Lovibond, Germany) photometer. The method of MD-600 photometer is a colorimetric assay and each nutrient is reacted with specific chemical reagents which give out the specific colour. The nutrient concentrations are positively correlated with the strength of the colour. The limit of detection of TDN, TDP, nitrate, ammonia and phosphate is $0.1 \mathrm{mg} / \mathrm{L} \mathrm{N}, 0.02 \mathrm{mg} / \mathrm{L}$ $\mathrm{P}, 0.08 \mathrm{mg} / \mathrm{L} \mathrm{N}, 0.02 \mathrm{mg} / \mathrm{L} \mathrm{N}$, and $0.05 \mathrm{mg} / \mathrm{L} \mathrm{P}$, respectively. The coefficient variance (CV) of each measurement was usually less than $2 \%$.

\section{RESULTS AND DISCUSSION}

\section{A. Physical and Chemical Properties of Water}

Physical and chemical parameters of river and mining pond water samples are shown in Table 1. Water temperature ranged from 21.7 to $29.6{ }^{\circ} \mathrm{C}$ in Selangor River and 28.0 to $31.4{ }^{\circ} \mathrm{C}$ in mining ponds. The water temperature of upstream was much lower than that of downstream. The $\mathrm{pH}$ values ranged from 7.13 to 8.52 in Selangor River, while 5.66 to 7.45 in mining ponds. The two mining ponds showed the acidic conditions. This could be due to high bacterial activities or acidic soil contaminants during the mining activities in the past. The DO concentrations ranged from 0.54 to $3.35 \mathrm{mg} / \mathrm{L}$ in Selangor River and 1.09 to $1.28 \mathrm{mg} / \mathrm{L}$ in mining ponds. The low DO concentrations in Selangor River and mining ponds could be due to the high bacterial activities, but we found that the dissolved oxygen meter was not properly calibrated during the sampling, leading to the low dissolved oxygen concentrations. The salinity was high at St 1 in Selangor River due to the high tide during sample collection. The high conductivity was also observed at St 1 due to the high salt contents. The rest of samples showed the low salinity ( $<0.23 \mathrm{ppt}$ ), and conductivity. However, the conductivity of mining pond 2 (MP2) appeared to be higher than other stations despite the low salinity. Conductivity is a measure of how well a solution conducts electricity. The water in MP2 could contain more ionic substances besides salts which may include heavy metals.

TABLE I

PHySicAl PROPERTIES OF WATER SAMPLES FROM SELANGOR RIVER AND MINING PONDS

\begin{tabular}{cccccc}
\hline Station & $\begin{array}{c}\text { Temperature } \\
\left({ }^{\circ} \mathrm{C}\right)\end{array}$ & $\begin{array}{c}\text { Salinity } \\
(\mathrm{ppt})\end{array}$ & $\mathrm{pH}$ & $\begin{array}{c}\text { Dissolved } \\
\text { Oxygen } \\
(\mathrm{mg} / \mathrm{L})\end{array}$ & Conductivity \\
\hline ST 1 & 29.0 & 24.31 & 8.19 & 3.35 & 42.680 \\
ST 2 & 29.6 & 0.23 & 8.52 & 0.54 & 0.520 \\
ST 3 & 27.1 & 0.07 & 7.70 & 2.41 & 0.151 \\
ST 4 & 26.6 & 0.04 & 7.59 & 1.74 & 0.086 \\
ST 5 & 25.4 & 0.02 & 7.48 & 0.72 & 0.056 \\
ST 6 & 24.7 & 0.01 & 7.27 & 0.74 & 0.031 \\
ST 7 & 24.1 & 0.01 & 7.35 & 1.23 & 0.020 \\
ST 8 & 22.0 & 0.01 & 7.13 & 1.12 & 0.021 \\
ST 9 & 25.5 & 0.01 & 7.16 & 0.91 & 0.019 \\
ST 10 & 21.7 & 0.01 & 7.31 & 0.71 & 0.028 \\
\hline $\begin{array}{l}\text { Mining } \\
\text { pond 1 }\end{array}$ & 31.6 & 0.04 & 5.95 & 1.09 & 0.098 \\
Mining & 31.4 & 0.02 & 5.66 & 1.12 & 0.484 \\
pond 2 \\
Mining \\
pond 3
\end{tabular}

\section{B. Nutrient Analysis}

The nutrient concentrations are shown in Table 2. The high ammonia concentrations were observed at St 2, 3, and 4 in Selangor River and MP2. The total nitrogen (TN) concentrations were quite high ( $\sim 13 \mathrm{mg} \mathrm{N} / \mathrm{L})$ at St 1 and 2 . The rest of samples showed the relatively low TN concentration. Total phosphorus (TP) concentrations were low at all stations. 
Nitrate concentrations were only high at St 2, and the rest of samples were low or below detection limit. The low concentrations of nitrite were observed in St 1, 2, 3, 4 and 5, and the rest was below detection limit. High level of ammonia and TN at St 1 and 2 could be due to the resuspension of sediment caused by high tide. The high turbulence of water was observed at St 1 and 2 during the sampling, resulting in the resuspension of sediment which includes the nitrogen. The high concentrations of ammonia observed in MP2 could be due to the contamination of mining soils, high bacterial activities, or both. In addition, the sand quarry was observed next to MP2. The contaminated soil from the quarry could be introduced to MP2 due to heavy rain or high wind. This needs to be further studied. Our results suggest that some of mining ponds could be the source of extra nutrients to Selangor River.

TABLE II

Nutrient Concentrations From SELANGOR River AND Mining PONDS (MG N OR P/L)

\begin{tabular}{cccccc}
\hline Station & Ammonia & $\begin{array}{c}\text { Total } \\
\text { Nitrogen }\end{array}$ & $\begin{array}{c}\text { Total } \\
\text { Phosphorus }\end{array}$ & Nitrate & Nitrite \\
\hline ST 1 & 0.010 & 13.0 & $\mathrm{UR}^{\mathrm{a}}$ & $\mathrm{UR}$ & 0.210 \\
ST 2 & 0.810 & 13.4 & 0.370 & 4.3 & 0.060 \\
ST 3 & 0.520 & 4.6 & $\mathrm{UR}^{\mathrm{a}}$ & 1.0 & 0.070 \\
ST 4 & 0.580 & 3.2 & 0.060 & 1.0 & 0.080 \\
ST 5 & $\mathrm{UR}^{\mathrm{a}}$ & 1.6 & 0.060 & $\mathrm{UR}^{\mathrm{a}}$ & 0.030 \\
ST 6 & 0.050 & 1.9 & 0.090 & $\mathrm{UR}^{\mathrm{a}}$ & $\mathrm{UR}^{\mathrm{a}}$ \\
ST 7 & 0.050 & $\mathrm{UR}^{\mathrm{a}}$ & 0.110 & $\mathrm{UR}^{\mathrm{a}}$ & $\mathrm{UR}^{\mathrm{a}}$ \\
ST 8 & 0.010 & $\mathrm{UR}^{\mathrm{a}}$ & 0.060 & $\mathrm{UR}^{\mathrm{a}}$ & $\mathrm{UR}^{\mathrm{a}}$ \\
ST 9 & $\mathrm{UR}^{\mathrm{a}}$ & $\mathrm{UR}^{\mathrm{a}}$ & $\mathrm{UR}^{\mathrm{a}}$ & $\mathrm{UR}^{\mathrm{a}}$ & $\mathrm{UR}^{\mathrm{a}}$ \\
ST 10 & $\mathrm{UR}^{\mathrm{a}}$ & 1.7 & $\mathrm{UR}^{\mathrm{a}}$ & $\mathrm{UR}^{\mathrm{a}}$ & $\mathrm{UR}^{\mathrm{a}}$ \\
\hline Mining & $\mathrm{UR}^{\mathrm{a}}$ & 0.9 & 0.220 & $\mathrm{UR}^{\mathrm{a}}$ & $\mathrm{UR}^{\mathrm{a}}$ \\
pond 1 & & & & & \\
Mining & 0.800 & 2.5 & $\mathrm{UR}^{\mathrm{a}}$ & $\mathrm{UR}^{\mathrm{a}}$ & $\mathrm{UR}^{\mathrm{a}}$ \\
pond 2 & & & 0.05 & $\mathrm{UR}^{\mathrm{a}}$ & $\mathrm{UR}^{\mathrm{a}}$ \\
Mining & $\mathrm{UR}^{\mathrm{a}}$ & 2.1 & & &
\end{tabular}

a: under range (UR)

\section{Heavy metal analyses}

Heavy metal results are shown in Table 3. Our results showed that heavy metal concentrations in Selangor River showed a strong gradient from upstream to downstream. The heavy metal concentrations in upstream points were very low. Most of them increased towards downstream. The significantly high concentrations of aluminum (Al) and iron (Fe) were observed in downstream points. These concentrations were well-above the allowance levels of $\mathrm{Al}$ and Fe determined by Internal National Water Quality Standards (INWQS) for Malaysia as well as World Health Organization (WHO). Compared to other rivers in Malaysia, these concentrations were much higher. The sampling point 2 showed the extremely high $\mathrm{Al}$ and Fe. During the sampling, the high turbulence was observed in the sampling point 2 due to the high tide. This indicates that the significantly high amount of $\mathrm{Al}$ and Fe are accumulated in the sediment of downstream of Selangor River as well as possibly the coastal areas. The mining pond 3 also showed the high concentrations of $\mathrm{Al}$ and Fe. The sampling sites of three mining ponds are located between sampling station 3 and 4 of Selangor River. The significant increase of $\mathrm{Al}$ and Fe was also observed from station 3 to 4 . This result indicates that the mining ponds could be the main source of $\mathrm{Al}$ and Fe. In addition, due to the recent water deficiency, the channel construction from mining ponds to Selangor River which allows the mining pond water continuously and steadily flow into Selangor River has been achieved. This could also contribute to accelerating the accumulation of $\mathrm{Al}$ and $\mathrm{Fe}$ in the downstream of Selangor River.

In another related finding, local newspaper has recently published an article about illegal sand mining around abandoned mining ponds near to the river at Rasa, Hulu Selangor [9]. These illegal mining could lead to further heavy metals being introduced into the adjacent rivers including Selangor River. It is also reported that numerous aquaculture farms are located along the Selangor River, especially between sampling station 5 and 7. Surveying around the aquaculture farms showed that most of the effluents or waste water was being discharged without proper treatment or none at all. The heavy metals such as $\mathrm{Fe}, \mathrm{Zn}, \mathrm{Cu}, \mathrm{Pb}$ and $\mathrm{Cd}$ were released from aquaculture farming practices [10]. This could also contribute to the high concentrations of heavy metals in stations 5 and 6.

$\mathrm{Al}$ and $\mathrm{Fe}$ are not listed as dangerous chemicals according to WHO. However, both heavy metals could cause many adverse effects on aquatic organisms as well as human health. Al can be accumulated in different organs of the aquatic organisms' body but respiratory disturbances due to interlamellar mucous clogging is found due to $\mathrm{Al}$ toxicity [10]. At high level, $\mathrm{Al}$ can be precipitated, and the membrane fluidity may be reduced. Osmoregulatory disturbances due to net loss in ion uptake $\left(\mathrm{Na}^{+}\right.$, $\mathrm{Cl}^{-}$and $\mathrm{Ca}^{2+}$ ) caused by $\mathrm{Al}$ binding to gill surface, intracellular $\mathrm{Al}$ accumulation, increased membrane permeability and damage of epithelium could happen to aquatic organisms. As for humans, Al could be distributed throughout the body and accumulated in bone, kidneys and brain with evidence of renal dysfunction, anemia or neurobehavioural alterations reported after excessive doses.

For Fe, it is not deadly to any aquatic animals at normal level, but at higher levels fish and other aquatic organisms cannot process all the iron and Fe can be accumulated in their body. The excess Fe can build up in animals' internal organs, affecting many adverse effects on their lives, and eventually killing them. Higher levels of Fe in fish and aquatic plants also have negative effects on the people or creatures which consume them. Fe poisoning is an Fe overload caused by a large excess of iron intake [11]. The first indication of Fe poisoning by ingestion is a stomach pain, as iron is corrosive to the lining of the gastrointestinal tract including the stomach. Iron poisoning can cause hypovolemic shock due to iron's potent ability to dilate the blood vessels. If not treated properly, these iron poisoning will lead to eventual death of the human.

Further studies of collecting more samples from different mining ponds are necessary to better estimate the potential amounts of heavy metals especially $\mathrm{Al}$ and $\mathrm{Fe}$ in the mining pond areas. The health effects of $\mathrm{Al}$ and $\mathrm{Fe}$ on different aquatic organisms as well as humans should be monitored to understand the impacts of $\mathrm{Al}$ and $\mathrm{Fe}$ on the natural environments and human societies. 
TABLE III

HEAVY METAL CONCENTRATIONS ALONG SELANGOR RIVER AND ADJACENT MINING PONDS AS WELL AS THOSE IN DIFFERENT RIVERS IN MALAYSIA. THE MAXIMUM ALLOWANCE LEVEL SET BY INTERNAL NATIONAL WATER QUALITY STANDARDS (INWQS) IN MALAYSIA AND WORLD HEALTH ORGANIZATION (WHO) ARE ALSO

\begin{tabular}{|c|c|c|c|c|c|c|c|c|c|c|}
\hline Station & $\mathrm{Al}$ & $\mathrm{Fe}$ & $\mathrm{Cu}$ & $\mathrm{Zn}$ & As & $\mathrm{Cd}$ & $\mathrm{Hg}$ & Se & $\mathrm{Pb}$ & Source \\
\hline ST 1 & NA & NA & NA & NA & NA & NA & NA & NA & NA & \\
\hline ST 2 & 2069.610 & 518.520 & 0.005 & 0.057 & 0.025 & $0.062 * 10^{-3}$ & $1.323 * 10^{-4}$ & 0.000 & 0.025 & \\
\hline ST 3 & 20.975 & 20.600 & 0.005 & 0.065 & 0.037 & $0.140 * 10^{-3}$ & $1.350 * 10^{-4}$ & 0.000 & 0.025 & \\
\hline ST 4 & 4.500 & 6.300 & 0.005 & 0.030 & 0.024 & $0.042 * 10^{-3}$ & $0.860 * 10^{-4}$ & $0.560 * 10^{-4}$ & 0.008 & \\
\hline ST 5 & 1.083 & 2.000 & 0.001 & 0.008 & 0.010 & $0.012 * 10^{-3}$ & $0.139 * 10^{-4}$ & $0.660 * 10^{-4}$ & 0.002 & \\
\hline ST 6 & 162.060 & 57.670 & 0.011 & 0.047 & 0.108 & $0.151 * 10^{-3}$ & $2.068 * 10^{-4}$ & 0.000 & 0.044 & \\
\hline ST 9 & 0.900 & 0.328 & 0.002 & 0.006 & 0.008 & $0.013 * 10^{-3}$ & $0.178 * 10^{-4}$ & $0.052 * 10^{-4}$ & 0.001 & \\
\hline ST 10 & 0.330 & 0.328 & 0.000 & 0.004 & 0.007 & $0.002 * 10^{-3}$ & $0.058 * 10^{-4}$ & $1.750 * 10^{-4}$ & 0.000 & \\
\hline Mining pond 1 & 0.415 & 0.215 & 0.001 & 0.010 & 0.010 & $0.040 * 10^{-3}$ & $0.193 * 10^{-4}$ & $1.665 * 10^{-4}$ & 0.000 & \\
\hline Mining pond 2 & 0.855 & 0.878 & 0.007 & 0.323 & 0.009 & $1.638 * 10^{-3}$ & $0.127 * 10^{-4}$ & 0.000 & 0.017 & \\
\hline Mining pond 3 & 38.75 & 15.975 & 0.006 & 0.041 & 0.047 & $0.06 * 10^{-3}$ & $3.400 * 10^{-4}$ & 0.000 & 0.032 & \\
\hline INWQS & 0.500 & 5.000 & 0.020 & 2.000 & 0.100 & $10^{*} 10^{-3}$ & $20 * 10^{-4}$ & $200 * 10^{-4}$ & 5.000 & \\
\hline WHO & 0.200 & NA & 2.000 & 3.000 & 0.010 & $3 * 10^{-3}$ & $10 * 10^{-4}$ & $100 * 10^{-4}$ & 0.010 & \\
\hline
\end{tabular}

\section{ACKNOWLEDGMENT}

The financial support is made by the Malaysia Ministry of Higer Education under Fundamental Research Grant Scheme (FRGS/1/2013/STWN01/UNISEL/02/1). Sampling was supported by numerous undergraduate students including Yaswini A/P Subramaniam, Vickneswary A/P Vadivelu and Fadzrina Dolhan. We also thank Joseph Anak Bidai at Universiti Malaysia Terengganu for the support of heavy metal analyses. We also would like to thank everyone who has indirectly contributed to this research.

\section{REFERENCES}

[1] Srivastava, S; Goyal, P (2010). Novel Biomaterials: Decontamination of Toxic Metals from Wastewater. Springer-Verlag. ISBN 978-3-642-11329-1. http://dx.doi.org/10.1007/978-3-642-11329-1

[2] Ten Chemicals of Major Public Health Concern. World Health Organisation. 2015.

[3] Bradl $\mathrm{H}$, editor. Heavy Metals in the Environment: Origin, Interaction and Remediation Volume 6. London: Academic Press; 2002.

[4] He ZL, Yang XE, Stoffella PJ. Trace elements in agroecosystems and impacts on the environment. $\mathrm{J}$ Trace Elem Med Biol. 2005;19(2-3):125-140.

http://dx.doi.org/10.1016/j.jtemb.2005.02.010

[5] Nriagu JO. A global assessment of natural sources of atmospheric trace metals. Nature. 1989;338:47-49.

http://dx.doi.org/10.1038/338047a0

[6] The Star Online. Selangor Rivers Polluted. available in http://www.thestar.com.my/news/nation/2012/10/12/selangor-rivers-pol luted/

[7] Road Transport Department Malaysia: Number of Other Vehicle Registrations According to Year, 2016. available at http://www.jpj.gov.my/en/statistics

[8] Banks D, Younger PL, Arnesen RT, Iversen ER, Banks SB. Mine-water chemistry: the good, the bad and the ugly. Environmental Geology. 1997;32(3):157-174.

http://dx.doi.org/10.1007/s002540050204
[9] The Star Online. Exclusive: Illegal sand mining at 'approved' site. available http://www.thestar.com.my/news/community/2013/08/12/illegal-sandmining-at-approved-site-company-carries-on-at-did-land-despite-expire d-permit/

[10] Rosseland, B.O., Staurnes, M., 1994. Physiological Mechanisms for Toxic Effects andResistance to Acidic Water: An Ecophysiological and Ecotoxicological Approach.In: C.E.W. Steinberg and R.F. Wright (Eds.), Acidification of Freshwater Ecosystems: Implications for the Future, pp 227-246. John Wiley \& Sons Ltd.

[11] Valentine, Kevin; Mastropietro, Christopher; Sarnaik, Ashok P. "Infantile iron poisoning: Challenges in diagnosis and management". Pediatric Critical Care Medicine 10 (3): e31-e33.

http://dx.doi.org/10.1097/PCC.0b013e318198b0c2

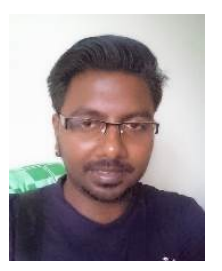

Daniel Ramachandran was born in Klang, Malaysia on November 21, 1987. He has obtained a Bachelor Degree in Industrial Biotechnology (Hons) with majoring in Microbiology from Faculty of Science and Biotechnology, University Selangor, Malaysia in 2013. He is currently pursuing a M.Sc. degree in Biotechnology at Faculty of Science and Biotechnology, University Selangor, Malaysia. He has worked at Department of Agriculture of Malaysia in 2012. Later in 2013-2014 he worked as Production Chemist (Production Person in charge \& R\&D) at Top Glove, F19/20, Malaysia. Since 2014, he has been working as Research Assistant for Dr. Nobuyuki Kawasaki at Faculty of Science and Biotechnology, University Selangor, Malaysia. His current research interests include water quality, molecular biotechnology and microbiology. 